Kong. Res. J. 1(1) : 122-124, 2014

Kongunadu Arts and Science College, Coimbatore

\title{
BIOLOGICAL TREATMENT OF YARN DYEING EFFLUENT BY PSEUDOMONAS SP.
}

\author{
Binukumari, S.* and J. Vasanthi \\ Department of Zoology, Kongunadu Arts \& Science College, Coimbatore. \\ *E-mail: binu.kumari@rediffmail.com
}

\begin{abstract}
The untreated effluents were collected from the Yarn dyeing industries at tirupur for the present study.The physico-chemical characteristics like Colour, Odour, Temperature, pH,TDS,TSS,BOD and COD was analysed before treatment.The effluent was treated biologically by Pseudomonas species.After treatment the pollution load reduction was observed significantly and the colour removal also reduced to a maximum level.
\end{abstract}

Key words: Yarn dyeing industry, biological, Pseudomonas, physico-chemical

\section{INTRODUCTION}

The Yarn dyeing and textile dyeing industries have a major share in polluting the aquatic bodies as well as lands and the effluents emanating from these industries have imparted colour to the ground water rendering them unsuitable for human consumption. According to Manivasakam (1995), about $50 \%$ of the total volume of the effluent from the textile processing is generated only from dyeing units.More than 8000 chemical product are associated with dyeing process (Society for dyers and Colourist,1976).

These effluents from dyeing industries require proper treatment before being let into the aquatic bodies or irrigation fields.The available physico-chemical treatment before methods are expensive and elaborate.Tortora et al.(1995) opined that microbial activity can be used to restore or maintain environment quality by biodegradation stimulation.Therefore, in the present investigation methods is attempted.

\section{MATERIALS AND METHODS}

\subsection{Collection of effluent samples}

Effluent from the yarn dyeing units at Tirupur was collected and used in this investigation.Soil samples collected from near the effluent flowing canals were used for the culture of the native bacteria. Bacterial strains belonging to pseudomonas spp. were identified from the samples based on the morphological characteristics using the procedures of Cappucino and Sherman (1999) and Kannan (1996).The physico-chemical characteristics of the diluted effluent were analysed following the standard procedures (APHA,1998) and then subjected to $1: 1$ dilution. After analyzing the physico-chemical characteristics of the diluted effluent, treatment studies were carried out.

\subsection{Treatment of effluent by Pseudomonas spp.}

To $100 \mathrm{ml}$ of the diluted effluent containing nutrient broth $1 \mathrm{ml}$ of bacterial inoculums was added and the mouth of the conical flask was plugged tightly.The conical flask were agitated in shaker at $120 \mathrm{rpm}$ for 24,48 and $72 \mathrm{~h}$ at $37^{\circ} \mathrm{C}$. The treated samples were analysed for physico- chemical characteristics. For colour removal study, OD values of samples were read at $620 \mathrm{~nm}$ using spectrophotometer. The concentration of dye present in the untreated and treated effluent was calculated referring to the OD value of the standard dyes solution and expressed in $\mathrm{mgl}^{-1}$.

\section{RESULTS AND DISCUSSION}

\subsection{Physico-chemical analysis of effluent}

The physico-chemical characteristics of the yarn dyeing effluent and the diluted effluent (1:1 ratio) are presented in Table 1.

The untreated effluent had a mixture of three dyes,Black B,yellow RML and red RB that imparted blackish brown colour.The effluent was odourless and the temperature was $60^{\circ} \mathrm{C}$ immediately after collection. The pH, TDS, TSS and COD levels were high and above the permissible limits prescribed limits prescribed by ISI standards for Industrial waste waters into public sewers.

The results of treatment of the effluent with Pseudomonas spp.are tabulated in Table II.By $48 \mathrm{~h}$ of the treatment a remarkable reduction in several parameters has been observed and the trend continued upto $72 \mathrm{~h}$ treatment.

\subsection{Reduction of Pollution load by Pseudomonas spp.}

A drastic reduction in $\mathrm{pH}$ from 10.7 in the diluted effluent to $7.57(29.25 \%)$ was observed by 24 h.Further decline in $\mathrm{pH}$ (7.29) was recorded by 48 
$\mathrm{h}$ and the same $\mathrm{pH}$ was maintained at $72 \mathrm{~h}$. The TDS level came down from $24,200 \mathrm{mgl}-1$ to $18,160 \mathrm{mgl}-1$ by $24 \mathrm{~h}$ showing a reduction of $24.96 \%$ in proportion to the duration of treatment,TDS level showed further reduction in $48 \mathrm{~h}\left(15,640 \mathrm{mgl}^{-1}\right)$ and $72 \mathrm{~h}$ (14,000 mgl-1) marking a percentage reduction of 42.15\%. Marginal reduction in TSS content was observed by $24^{\text {th }}$ and $48 \mathrm{~h}(12,800 \mathrm{mgl}-1)$ and $72 \mathrm{~h}$ $\left(12,050 \mathrm{mgl}^{-1}\right)$.

The BOD level at $24 \mathrm{~h}$ treatment $\left(150 \mathrm{mgl}^{-1}\right)$ as observed in the present study may be attributed to the initial utilization of $0_{2}$ by bacterial culture from the medium. By 48 h,however the BOD level was reduced to $136 \mathrm{mgl}^{-1}$ showing $18.07 \%$ reduction

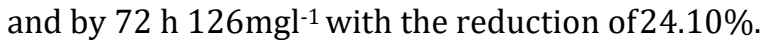

Significant reduction in COD was recorded in these treatments.The COD level in the untreated effluent was $230 \mathrm{mgl}^{-1}$ and this got reduced to 72 $\mathrm{mgl}^{-1}$ by $24 \mathrm{~h}$ showing $68.70 \%$ reduction, $12.0 \mathrm{mgl}^{-1}$ by $48 \mathrm{~h}$ and $8.8 \mathrm{mgl}^{-1}$ by $72 \mathrm{~h}$ showing a reduction of $94.78 \%$ and $96.17 \%$ respectively.Maximun reduction of BOD and COD could be obtained by $48 \mathrm{~h}$ itself.

Kanekar and Sarnaik (1995) reported that dye industry effluent in treatment with P.alkaligenes remained stable at $\mathrm{pH}$ 8.02.A reduction of $51 \% \mathrm{COD}$, $82 \%$ BOD,74\% TDS, $75 \%$ phenol and $60 \%$ colour in terms of methyl violet was reported in this work.In the present study, a further reduction of $\mathrm{pH}$ upto 7.29 and reduction of $42.15 \%$ TDS, $6.35 \%$ TSS, $24.10 \%$ BOD and $96.17 \%$ COD was recorded.

\subsection{Decolourisation}

Biodegradation of dye in the effluent was followed spectrophotometrically. The reduction in the dye concentration was found to be directly proportional to the duration of treatment (Table III). The diluted effluent had a dye concentration of $258.37 \mathrm{mgl}^{-1}$.This was reduced to $225.07 \mathrm{mgl}^{-1}$ showing a reduced of $47.14 \%$ by $24^{\text {th }}$.Further reduction to $170.10 \mathrm{mg}-1(69.63 \%)$ was observed in $48 \mathrm{~h}$ and thereafter a gradual decline in dye concentration was observed upto $96 \mathrm{~h}$ (76.86\%).No significant reduction could be recorded beyond this hour. $\mathrm{Hu}$ (1994) demonstrated a decolorisation of 37.4\% red G,93.2\% RBB,92.4\% RP2B and 88\% V2RP using Pseudomonas luteola within 48 h.Oxspring et al.(1996) using microbial consortium of Alcaligenes faecalis and Commamonas acidiverans in a gravel substratum found a decolourisation of $95 \%$ of Ramazol Black B within 48 h.In the present study using Pseudomonas spp., maximum colour removal of $76.83 \%$ could be obtained by 96 h.This falls in line with the findings of nigam et al.(1996) who reported
$70 \%$ removal of colour from textile plant effluent after 3 days treatment using a microbial consortium.

\section{CONCLUSION}

Biological treatment using Pseudomonas spp. in this investigation throws light on effectiveness of this microbe in reducing the pollution load as well as in the decolourisation process.Therefore, micro organisms are increasingly being focused on biological methods for the degradation and elimination of these pollutants in the effluents.

\section{REFERENCES}

APHA, (1998). Standard methods for the examination of water and waste water $\left(20^{\text {th }}\right.$ edition),American Public Health Association,Washington D.C.

Cappuccino, J.G. and N. Sherman,(1999). Biochemical activities of microorganisms.Microbiology- A laboratory manual.The Benjamin/ Cummings Publishing company, Inc., USA, pp.1-477.

Hu, T.L. (1994). Decolourization of reactive azo dyes by transformation with Pseudomonas luteola.Bioresource technol., 49:47-52.

Kanekar and Sarnaik, (1995).Microbial process for treatment of phenol bearing dye industry effluent in a fixed film bioreactor. J.Environ. Sci. Hlth., 30(8): 1817-1826.

Kannan, N. (1996). Physiological characteristics of microorganisms.Laboratory manual in general microbiology. Palani paramount Publication, Palani. pp.1-316.

Manivasakam, N. (1995). Treatment of textile processing effluents. Sakthi Publications, Coimbatore.pp.1-269.

Nigam, P., G. McMullan, I.M. Banat and R. Marchant, (1996). Decolorisation of effluent from the textile industry by a microbial consortium. Biotechnol.Lett., 18 :117-120.

Oxspring, D.A., G. McMullan, W.F. Smyth and R. Marchant, (1996). Decolorisation and metabolism of the reactive textile dye,Remazol Black B, by an immobilized microbial consortium. Biotech.Lett., 18(5): 527-530.

Society of Dyers and colourist, (1976). Colour Index $3^{\text {rd }}$ Edn. Yorkshire,U.K.

Tortora, G.T., B.R. Funke and C.L. Case, (1995). Bacteria. In: Microbiology, An introduction V.ed. The Benjamin/Cummings Publications, USA, pp. 27-281. 
Table 1. Physicochemical characteristics of yarn dyeing effluent.

\begin{tabular}{cccc}
\hline Parameters & $\begin{array}{c}\text { ISI Standards for Industrial waste water } \\
\text { into public sewers }\end{array}$ & $\begin{array}{c}\text { Untreated } \\
\text { effluents }\end{array}$ & $\begin{array}{c}50 \% \text { Diluted } \\
\text { Effluents }\end{array}$ \\
\hline Colour & - & $\begin{array}{c}\text { Brownish black } \\
\text { Odourless }\end{array}$ & $\begin{array}{c}\text { Brownish black } \\
\text { Odourless }\end{array}$ \\
Odour & - & $60^{\circ} \mathrm{C}$ & $32^{\circ} \mathrm{C}$ \\
Temperature & - & 10.9 & 10.7 \\
pH & $5.5-9.0$ & 53300 & 24200 \\
Total Dissolved Solids & 2100 & & \\
(TDS) & & 20800 & 12867 \\
TSS & 750 & 300 & 166 \\
BOD & 500 & 522 & 230 \\
COD & 250 & & \\
\hline
\end{tabular}

Table 2. Efficacy of Pseudomonas sp. in the reduction of pollution load.

\begin{tabular}{|c|c|c|c|c|c|c|c|}
\hline \multirow[b]{2}{*}{ Parameters } & \multirow{2}{*}{$\begin{array}{l}\text { Diluted } \\
\text { effluent }\end{array}$} & \multicolumn{3}{|c|}{ Treatment duration } & \multicolumn{3}{|c|}{ Reduction } \\
\hline & & $24 \mathrm{~h}$ & $48 \mathrm{~h}$ & $72 \mathrm{~h}$ & $24 \mathrm{~h}$ & $48 \mathrm{~h}$ & $72 \mathrm{~h}$ \\
\hline $\mathrm{pH}$ & 10.7 & 7.57 & 7.29 & 7.29 & 29.25 & 31.87 & 31.87 \\
\hline TDS & 24,200 & 18,160 & 15,640 & 14,000 & 24.96 & 35.37 & 42.15 \\
\hline TSS & 12,867 & 12,800 & 12,800 & 12,050 & 0.52 & 0.52 & 6.35 \\
\hline BOD & 166 & 150 & 136 & 126 & 9.64 & 18.07 & 24.10 \\
\hline COD & 230 & 72 & 12 & 8.8 & 68.70 & 94.78 & 96.17 \\
\hline
\end{tabular}

All parameter except $\mathrm{pH}$ is expressed in $\mathrm{mg}-1$

Table 3. Efficacy of Pseudomonas sp.in colour removal of yarn dyeing effluent.

\begin{tabular}{ccc}
\hline Duration of treatment & Dye concentration & \% Reduction \\
\hline $24 \mathrm{~h}$ & 225.07 & 47.14 \\
$48 \mathrm{~h}$ & 170.10 & 60.05 \\
$72 \mathrm{~h}$ & 129.32 & 69.63 \\
$96 \mathrm{~h}$ & 98,053 & 73.55 \\
$120 \mathrm{~h}$ & 112.63 & 76.86 \\
\hline
\end{tabular}

Dye concentration of untreated effluent - $425.80 \mathrm{mgl}-1$

Dye concentration of diluted effluent - $258.37 \mathrm{mgl}-1$ 